DOI : $10.24260 /$ khatulistiwa.v8i1.1205

\title{
THE DEATH TRADITION OF MALAY COMMUNITIES OF SUNGAI RAYA DALAM VILAGE, WEST KALIMANTAN
}

Mahdi

,Regional Office of Religious Affairs Ministry of West Kalimantan

Email: mahdisiregar70@gmail.com

\section{HIGHLIGH}

- Tradition Regarding to the Death of the Malay Community

- Tradition Ahead of Sakaratul Maut (closing the death time)

- Tradition After Death People

- Malay in West Kalimantan

\section{ARTICLE HISTORY}

$\begin{array}{lll}\begin{array}{l}\text { Submitt } \\ \text { Revision }\end{array} & : & \text { 8 Jan } 2018 \\ \text { Revision } & \text { : } & \text { 15 Feb } 2018 \\ \text { Minor } & & \\ \text { Accepted } & : & \text { 2 Mar } 2018 \\ \text { Published } & : & \text { 10 Mar } 2018\end{array}$

KHATULISTIWA: Journal of Islamic Studies Vol. 8, No. 1. March 2018

\begin{abstract}
Islam and culture cannot be separated since there are already Shari'a provisions about certain thing. However, when the Shari'a is practiced, it needs human interpretatation to understand. So, it will show one form of culture. This paper describes the form of the Malay community tradition in West Kalimantan in welcoming death. In Islam, if someone dies, there is an obligation for the living person to bathe, forgive, overtake and bury. In addition to these provisions, in practice, in the midst of the Islamic community, Malays in Sungai Raya Dalam, there is a tradition of mourning, handling bodies, until tahlilan after the body is buried. This tradition shows how the local culture relates to Islam. At the same time, showing Islam and local culture complement each other in the space of life of the Malay community.
\end{abstract}

Keyword : $\quad$ Death Tradition, Culture, Malay Kalbar 


\section{A. INTRODUCTION}

Death is a necessity. In Islamic theology it is called sunnatullah, so it certainly happens (Rasyid, 2000). All religions believe that all people will die, the diverse is the way of people's respond when there are people dies. These differences may be due to cultural factors or a religious belief of people in their lives.

Every community has its own traditions. For example people in the Malay community (see Djar'ie, SM, \& Prasojo, SH (2016), Kadir, MD, Yunus, A., \& Maria, S. (1985). In Chinese (see Yusuf, IA (2005), on Dayaks (See Kalista, 2018), they inherit or continue the tradition from previous people, and then decide to use it in whole, or in part, in their lives. In some circumstances, that tradition can be characteristic of certain groups (See Embong, 2011).

Through this paper the author will describe the tradition surrounding death in the Malay community, at Griya Husada Complex, Sungai Raya Village, in Sungai Raya Subdistrict, in responding if there are people who have passed away.

\section{B. METHOD}

This field research was conducted by the author last time ago. The researcher took data from residents of Sungai Raya Dalam at Griya Husada Complex in July 2015, with interviews and observations. Some people, including mosque administrators, have been used as data sources.

Residents in this complex numbering more than 450 families, consisting of various ethnicities, cultures and religions. From the Population Community of Griya Husada Complex, the majority (+75\%) are ethnic Malay and they are Muslim. The Malay people entered the Sungai Raya Dalam Griya Husada Complex starting when the complex was built for residential areas in 1996 - 1998, the Malay tribe came from the Sambas, Singkawang, Ketapang, Kapuas Hulu, Mempawah, Kubu Raya and Pontianak City, but the majority from is the Sambas Regency. Over time, residents who came from various tribes then lived and formed a new culture, culture that was practiced in the region. After collecting the data, it is then grouped based on the needs of this research and conclusions are then made. After that, it is analyzed, and presented.

KHATULISTIWA: Journal of Islamic Studies Vol. 8, No. 1. March 2018
DOI: 10.24260/khatulistiwa.v8i1.1205

The Death Tradition of Malay Communities of Sungai Raya Dalam Village, West Kalimantan 


\section{RESULT AND DISCUSSION}

\section{Malay Tradition}

For Malay people in the Griya Husada Sungai Raya Dalam Complex, Pontianak, the death is a sacred event that has its own meaning and believed to be the entrance to a new round of life. Because death has an important meaning as the entrance to the next round of life, then every time a death occurs, the complex community reacts to it seriously, so that the person who dies is successful and safely enters his new life. There are a number of traditions carried out by the community and have become a rooted culture in the Malay community of Sungai Raya Dalam Griya Husada Complex, including:

\section{Welcoming of Sakaratul Maut}

If there are people who are sick and believed that his/her death is imminent, the family usually gather to accompany the sick waiting for his death to come, as well as the neighbours come to visit him/her with two purposes, first to see the condition of the sick while praying for him to recover while guiding him kalimah thoyyibah, second to show empathy for the sick family. It has become a culture of complex society, when going to visit the sick, they do not forget to bring foods, sometimes fruits, snacks and envelopes containing money. The nominal amount of money in the envelope varies greatly, depending on the social status of the visitor's and who is visited and the closeness of the visitor to the sick person or his family. In the case of ordinary social status and closeness, the nominal amount of money in the envelope is around Rp. 20,000, - to Rp. 50,000, - As for closer relations the amount donated through the envelope is even greater.

KHATULISTIWA: Journal of Islamic Studies

Vol. 8, No. 1. March 2018
DOI: $10.24260 /$ khatulistiwa.v8i1.1205

The Death Tradition of Malay Communities of Sungai Raya

Dalam Village, West Kalimantan 


\section{After Death}

If he has been declared dead, the first step taken by the family is to remove all objects attached to the body, straighten his body, close his eyes and mouth, and put his hands on his chest in a position as if he were to pray, lay his body lying on his head in the east, then cover his entire body with several layers of cloth. Furthermore, notices to neighbourhood about the death, both through verbal communications by informing door to door or by telephone communication and Darussyakirin's mosque loudspeakers. Announcements through mosques are usually carried out by mosque administrators whether requested or not by the family, because it has become a tradition, spontaneously the mosque officials announce it.

After hearing the news the neighbours arrived for takziah. If it dies in the afternoon or at night (before midnight) the neighbours who come are more crowded than if the death above midnight or early morning. If he dies at midnight or early in the morning, people arrive in the morning, and for those who have to work on that day, they usually arrive earlier and don't have a moment and if possible he will come again at the funeral.

Before the mourners came to ta'ziah, the body was laid in the middle room, positioned facing the Qibla with clothes still attached to his body, his entire body was covered with 2 layers of long cloth, left and right propped up with pillows or bolsters. Around the deceased are provided the Koran and the surah Yaasin for mourners who want to read it. Being in front of the house, Tarups or tents and chairs for mourners were put to rest waiting until the bodies were buried.

\section{Takziah Tradition}

It is already a culture of complex society, takziah is considered an "obligation" of humanity. Residents come with various models, some of them come and greet other neighbours (not at home to see the body) then sit down with other residents while chatting until the time he goes home. But many of them also came to greet residents and families and then entered the house, put envelopes filled with money into the boxes / places that had been provided, the nominal was between Rp. 20,000, - d.d 50.000, - then open the cloth covering the body, then rub the head or face (of course with regard to sex) while praying for the body,

KHATULISTIWA: Journal of Islamic Studies Vol. 8, No. 1. March 2018
DOI: $10.24260 /$ khatulistiwa.v8i1.1205

The Death Tradition of Malay Communities of Sungai Raya Dalam Village, West Kalimantan 
then cover the cloth again, then sit around the body while praying or reading the Quran or Surah Yaasin.

\section{Implementation of Fardhu Kifayah}

While the neighbours came to mourn, the family together with religious leaders and administrators Fardu Kifayah discussed the next process. Because in the Griya Husada Complex there are administrators of fardu kifayah, then the next process is handled by officers ranging from bathing, memorizing, passing to the funeral. Another case for families who want to take care of their own needs, then their administrators only help. Next is the fardu kifayah process:

Bathe. After being agreed upon by the family about funeral time, the bathe procees depends on the family agreement. If he/she dies in the afternoon or evening, then the funeral time is held the next day at $10 \mathrm{am}$, if he dies in the morning, then the funeral is carried out after the zuhr prayer, but if he dies at around 10 a.m. after completing the asr prayer, but if he dies above 12:00 noon, then the funeral process is waiting for tomorrow morning, then the next is the bathing process.

If the body is male, the process of bathing it by fardu kifayah officers and they don't get paid. However while if the body is a woman, it is due to the Griya Husada complex that there are no fardu kifayah officers for female bodies, so the family is assisted by management from the outside the complex to bathe while at the same time memorizing it, usually 2 to 4 people, they were picked up they get paid around Rp. 100,000, - / person.

While the body was bathed, mothers and close neighbors prepared meals for families who came from far place and the community who participated in helping the funeral process. The source of funds used to prepare food and drinks come from social funds collected by social gathering of women around Rp. 2,000, - per house / month.

Usually the body is bathed in the back of the house. Because the houses now in the complex already use cement floors, then the corpses are put on their family laps or use special table, in out door of the house which has covered with cloth or plywood. In the process of bathing, usually the close family (male side) participates in the process, some are in charge of laps, rubbing, watering and preparing water.

KHATULISTIWA: Journal of Islamic Studies Vol. 8, No. 1. March 2018
DOI: $10.24260 /$ khatulistiwa.v8i1.1205

The Death Tradition of Malay Communities of Sungai Raya Dalam Village, West Kalimantan 
Dealing with it, 5 men from the family side or residents who were asked for help, sat leaning against the wall with straight legs (stretched), then the bodies were placed on their laps, some of them were holding the head, chest, waist, thighs and legs . The priority for the bathing process is the pardhu kifayah officer assisted by the family. The body is bathed with water and soap, and there is also a mixture of water with camphor, after being clean, the body is in place and dried using a towel, then lifted to the living room that has been prepared.

\section{Forgiveness}

After the body is bathed and has been lifted to the middle room, then the next process is to forgive. The corpse is carved with 3 or 5 layers of white cloth. 1 layer of the cloth is cut to be used as binder and clothes in the corpse, while the other 2 layers are as bandages / wrappers. Before the body is wrapped, in certain parts of the body affixed with cotton that has been given perfume, then bandaged and tied with 5 ties (the top of the head, chest, waist, legs and underfoot). After it is overlaid.

\section{Obey}

Before the corpse is delivered to the cemetery, the corpse is first overlaid. The implementation of prayers is usually carried out in the house, except when the family requests it to the mosque. In the implementation of the prayer body is usually led by local religious leaders, followed by some families and communities, usually they are not as many as those who come to mourn. In fact, it is common for close family members not to participate in the case.

The process of pray sometimes at Darussyakirin Mosque, but more often at the deceased's house. If the prayers are in the mosque, the residents are in the mosque, but if the prayer is held at home, ablution is at home, while those who live far away, then ablution is at the house of the death/ is also at or stay in neighbor's house.

\section{Buried}

Dealing with the coffin, it was prepared by the residents, by buying boards and nails or there were parties who donated, then the board was worked in a crowd by residents so

KHATULISTIWA: Journal of Islamic Studies Vol. 8, No. 1. March 2018
DOI: $10.24260 /$ khatulistiwa.v8i1.1205

The Death Tradition of Malay Communities of Sungai Raya

Dalam Village, West Kalimantan 
that it became a coffin. However, in the last 10 years, the coffins were no longer worked on by residents, but were purchased at the Darunnajah Sungai Raya mosque in 1 set, including cloth, tombstones, cotton, perfume and other equipments. The price of 1 set is Rp. 800,000, -

After completing the funeral prayer, the body is put in a coffin and appointed using a coffin, then taken to the yard, the coffin of the body is stopped for a moment, then the family conveys a word about apologies all mistakes and mistakes on behalf of the deceased. The neighbours who have the debts problem of the deceased in order to immediately contact the family. Then the corpse was escorted to the cemetery, if the burial place was far from the complex, it was ushered by an ambulance, but if the burial place was near to the complex, the corpse was carried together by families and residents of the complex.

For residents of the deceased complex it is usually buried in the waqf land around the complex (except if the family asks some whereelse), the location of the tomb is not paid, only the grave digger is paid Rp. 400,000, - for 4 people, the grave digging officer has been determined by the waqf land manager.

The burial procession was guided by grave diggers. The grave digger officers prepared two pieces of wood and two ropes (mines). Wood serves to place the coffin, while the rope is to lower the coffin. Then two pieces of wood and two ropes are stretched over the grave hole, and the coffin is placed on top of it. After everything is ready, the mourners hold 4 ends of the rope, over the grave digging command, the rope is pulled as hard as possible until the coffin is lifted. When the coffin is lifted, two supporting logs are removed, then the casket is lowered slowly. After the coffin reaches the bottom, then two ropes are pulled back, then the grave hole is buried with soil.

After the body is buried, the tomb is buried with soil and raised, then above the grave is marked (nisan) which has been written with the name, place and date of birth and the date of his death. Above the grave is sprinkled with flowers and doused with water mixed with Agar wood powder.

After completing the entire funeral process, it was continued with tahlil, talqin and prayer led by local religious leaders. One of the family members stood up and expressed his gratitude as well as conveying an invitation to all mouners to the evening prayer at the house of the deceased. Tahlilan is usually held for three consecutive nights. On the first and second

KHATULISTIWA: Journal of Islamic Studies Vol. 8, No. 1. March 2018
DOI: $10.24260 /$ khatulistiwa.v8i1.1205

The Death Tradition of Malay Communities of Sungai Raya Dalam Village, West Kalimantan 
night of the day, residents were served to tea or coffee and snacks, while on the third night, residents were usually given a complete rice dish. This is done as a form of thanking the family to all residents for the prayers that have been offered so that the deceased is freed from the torment of the grave and survives in the next life. Then on the 7th, 40th, 100th and 1000th days there will be an invitation to the tahlilan again, in order to remember and pray for the deceased.

\section{CONCLUSION}

The data above shows that in Malay society in Sungai Raya In Pontianak the tradition surrounding death has a connection between religion and culture. The way Malay people organize their bodies follows the ways regulated in Islam in accordance with the guidance of Islamic fiqh. That is, if someone dies, his body is bathed, covered, and then buried. That obligation is taught by Islamic law.

There is guidance on Islamic fiqh on that matter (Rasyid, 2000), Among these obligations, in its implementation, there are local cultural traditions carried out. For example, when the death is reportedly delivered at the mosque, at the death home, spontaneously the neighbours put the tent and borrow chairs for the mouners.

When the body is buried, he transported with a coffin. Then after being buried, tombs were placed on top of the tomb with a distinctive name and shape, then on top of the tomb were sprinkled with flowers, and watered with water mixed with agarwood powder. After someone died, the Yasin and Tahlil were read for three consecutive nights, known as the first night, the second night, and the third night. At this event the menu served is differently.

This tradition shows how the local culture relates to Islam. Local culture means, the culture carried out by the local community - even though some things are also related to culture in other places. This also shows that Islam and local culture fill each other in the living space of the Malay community. For them, this tradition of death has been carried out since a long time ago and those who are now inherit it.

KHATULISTIWA: Journal of Islamic Studies Vol. 8, No. 1. March 2018
DOI: 10.24260/khatulistiwa.v8i1.1205

The Death Tradition of Malay Communities of Sungai Raya Dalam Village, West Kalimantan 


\section{BIBLIOGRAPHY}

Djar'ie, S. M., \& Prasojo, Z. H. (2016). Religion, Culture and Local Wisdom in the Death Ritual of Pontianak Malay Society. Al-Albab, 4(2), 201-216.

Kadir, M. D., Yunus, A., \& Maria, S. (1985). Upacara tradisional (upacara kematian) daerah Riau. Departemen Pendidikan dan Kebudayaan, Proyek Inventarisasi dan Dokumentasi Kebudayaan Daerah.

Kalista, V. (2018). Puncak Ritual Kematian Suku Dayak Tonyooi Benuaq dalam Dokumenter Etnografi "Malas Budi Basaq" (Doctoral dissertation, Institut Seni Indonesia Yogyakarta).

Rasyid, S. (1990). Fiqh Islam Lengkap. Jakarta: At-Thahiriyah.

Yusuf, I. A. (2005). Media, kematian, dan identitas budaya minoritas: representasi etnik

Tionghoa dalam iklan dukacita. UII Press

KHATULISTIWA: Journal of Islamic Studies

Vol. 8, No. 1. March 2018
DOI: 10.24260/khatulistiwa.v8i1.1205

The Death Tradition of Malay Communities of Sungai Raya

Dalam Village, West Kalimantan 